症例

術後 5 年間生存中の虫垂粘液囊胞腺癌による腹膜偽粘液腫の 1 例

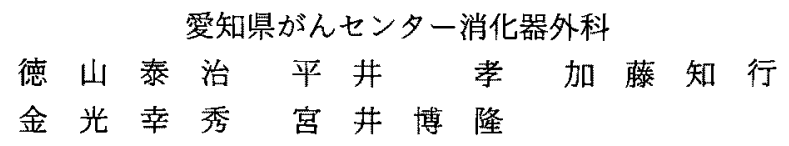

術後 5 年間無再発生存中の虫垂粘液賈胞腺癌による腹膜偽粘液腫の 1 例を経験したの で, 若干の文献的考察を加え報告した。症例は61歳女性, 下腹部膨満を主訴に近医を受 診. 大腸内視鏡およびCT 所見から盲渴癌, 両側卵巣転移々䛦断され, 当院へ紹介され た。手術所見では右卵巣, 盲腸, 虫垂が一塊となっていた。また，腹腔内には粘液が貯 留し,さらに粘液結節が大網, 脾蔵周囲, ダグラス䔰に存在した. 子宮両付属器, 大網, 右半結腸, 脾臟とともに粘液結節を亟力摘出し腹腔内を $5 \%$ \%゙ドウ梼溶液にて洗浄し術 後にシスプラチン腹肤内投与を繰り返した. 病理組織学的には虫垂粘液襄胞腺癌による 腹膜偽粘液腫で粘液性腹水には癌細胞を認めない typeであった。

索引用語：腹膜偽粘液腫，虫垂粘液䓰胞腺癌

\section{緒言}

腹膜偽粘液腫は腹腔内に多量の粘液梯物質が貯留す る比較的稀な疾患単位である. 近年本疾患を良悪性を 基に分類する試みがなされている。また治療法として 良恶性を問わず reduction surgery が一般的である が, 追加化学療法に関しては評価が定まっておらず, 特に悪性例での長期生存例は稀である。.今回, われわ れは reduction surgery 上術後シスブラチン腹腔内投 与により 5 年問長期生存中の腹膜偽粘液腫の 1 例を経 験したので新しい分類に関する若干の文献的考察を加 えて報告する。

症例
症例 $: 61$ 歳, 女性.
主訴: 下腹部鼔満感。

既往歴, 家族歴：特記すべき事なし。

現病歴: 平成 10 年 8 月初旬加ら下腹部腫瘤を触知 し, 近医を受診. 腹部 CT 検查により盲腸癌, 両側卵 巣転移と診断され治療目的にて当院へ紹介された。

入院時現症: 身長 $156 \mathrm{~cm}$, 体重 $51 \mathrm{~kg}$. 下腹部正中に 直径 $20 \mathrm{~cm}$ 大の可動性のある腫溜を触知した。また,それ とは別に右側腹部にも直径約 $8 \mathrm{~cm}$ の腫瘤を触知した。

2004年 2 月 25 日受付 2004 年 4 月19日採用

〈所属施設住所〉

厂464-8681 名古屋市千種区鹿子殿 $1-1$
入院時血液検査所見：へモグロビン $10.8 \mathrm{~g} / \mathrm{dl}$, 血清 鉄 $32 \mu \mathrm{g} / \mathrm{dl}$ と鉄欠乏性賀血を認めCEA : $12.8 \mathrm{ng} /$ $\mathrm{ml}, \mathrm{CA} 19-9: 75 \mathrm{U} / \mathrm{ml}, \mathrm{CA} 125: 44 \mathrm{U} / \mathrm{ml}$ と高値を示し た.

腹部 CT 検查所見：下腹部にわずかな造影効果のあ る隔壁構造を伴う径 $20 \mathrm{~cm}$ の堙胞性腫瘤と盲腸壁の肥

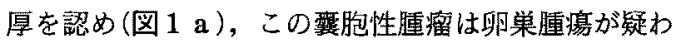
れた。脾臟には磌側からの粘液塊に上る圧排を示す弧 状㢻入, 弧状石灰化像を諗め, 両横隔膜下に液体貯留 を認めた（図 1 b).

大腸内視鏡検査：盲腸に粘液分泌の豊富な 1 型腫瘤 を認めた（図 2 ). 生検で signet-ring cell carcinoma と診断された。

以上の所見より, 盲腸癌, 卵巣転移, 腹膜播種との 診断にて同年10月 9 日開腹術を施行した。

手術所見：腹腔内にゼリ一状の粘液が貯留してお り, 径 $17 \mathrm{~cm}$ の腫瘤を右卵栄, 盲腸, 虫垂と一塊となっ て形成していた。左卵巣は径 $5 \mathrm{~cm}$, 結節状に腫大して いた。さらに粘液結節が腹腔内に点在し大網, 脾淢周 囲,ダグラス䆟に腫瘤を形成していた。緊急腹水細胞 診で良悪性境界の紐胞を認め腹膜偽粘液腫と診断し, 子宫両付属器, 大網, 右半結腸, 脾臓を摘出した。肝 表面や他の粘液結節を極力摘出し $1 \mathrm{~cm}$ 以上の腄瘦を 腹腔内に残存しないようにした，腹腔内を $5 \%$ ブドウ 糖溶液 $3 \mathrm{~L}$ にて洗浄後, 右下腹部からダグラス裔に腹 

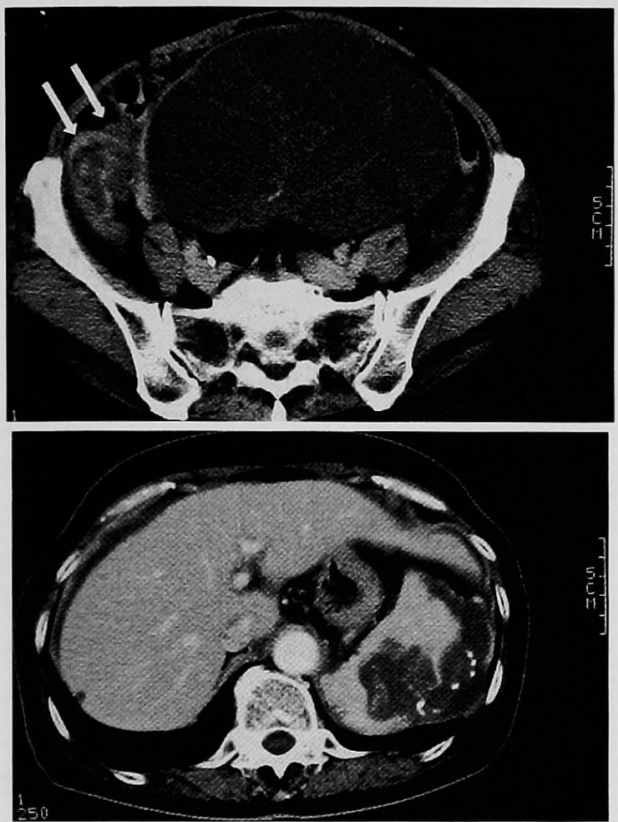

図 1 腹部 $\mathrm{CT}$ 検査

a：下腹部にわずかな造影効果のある隔壁構造を 伴う径 $20 \mathrm{~cm}$ の慗胞性腫瘤と盲腸壁の肥厚 (矢印) を認めた。

b : 脾藏に頭側からの粘液塊による圧排を示す弧 状羉入, 弧状石灰化像を認め, 両横隔膜下に液体貯 留を認めた。

腔内投与用の皮下埋め込みリザーバーである Port cath を留置した。

摘出標本所見: 右卵巣が径 $17 \mathrm{~cm}$ に腫脹し盲腸, 虫

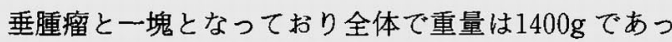
た。盲腸の虫垂開口部近くには 1 型腫愓を認め（図 3 a ), ホルマリン固定後の切断面においてこの腫崵は上 皮から由来していることを確認できた（図 3 b).

病理組織学的所見：盲腸虫垂開口部近くの腫瘍は粘 液産生の強い高分化型腺澏で粘液で満たされた䡠胞を 形成していた（図 4 a ）。また，右卵巣（図 4 b)，子 宮, 脾臓は, 異型度の低い粘湤産生細胞に裹打ちされ

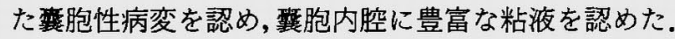
腹腔内の粘液には癌細胞を認めなかった，以上より虫 垂原発の粘液賈胞腺癌による腹膜偽粘液腫と診断され た。

術後経過：サブイレウス状態が長びいたために術後 48日目より，卵巣癌に対するプロトコールに準じて腹 腔リザーバーよりシスプラチン (以下 CDDP) $200 \mathrm{mg} /$

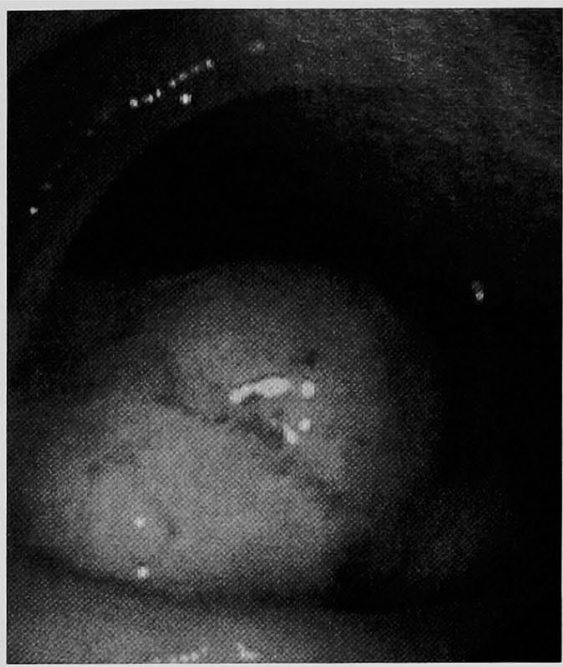

図 2 大腸内視鏡検查：盲腸に粘液分泌の豊富 な 1 型腫瘤を認めた。

生食 $2 \mathrm{~L}$ 腹腔内投与とチオ硫酸ナトリウム $12 \mathrm{~g}$ の静脈 投与を開始，以後 4 週間隔で繰り返した，平成 12 年 3 月，18回目を終了した時点で手掌，足蹠のしびれが強 くなり腎機能の軽度悪化を認め中止した。腫敀マ一カ 一は術直後より正常化し，5年後の現在まで上昇を認 めない．腹部 CT でも，明らかな腹腔内再発を認めて おらず無再発生存中である。

\section{考 察}

腹膜偽粘液腫 (pseudomyxoma peritonei：以下 PMP) は腹腔内に粘液性腹水が貯留する比較的稀な疾 患単位である"．しかし，治療や予後を考慮するうえで PMPには原発巣臓器, 悪性度からみて種々のものが 混在しているという問題がある.かつてはそのほとん どが虫垂, 卵巣の粘液性腺腫の破綻によるものとされ た、特に女性では両者に病変を認める例が多く原発巣 の特定が困難であったが，最近の数々の分子生物学的 な研究から PMP は注とんどが虫垂原発であって卵巣 病変は 2 次的な転移によるものであると結論づけられ ている2)

一方，PMP を良悪性に基づいて分類しょうという 試みもなされている. Ronnet ら DPAM : disseminated peritoneal adenomucinosis PMCA : peritoneal mucinous carcinomatosis, PMCA-I/D : peritoneal mucinous carcinomatosis with intermediate or discordant features $に$ 分類し た。そして，その転帰を見たところ，5年，10年生存 


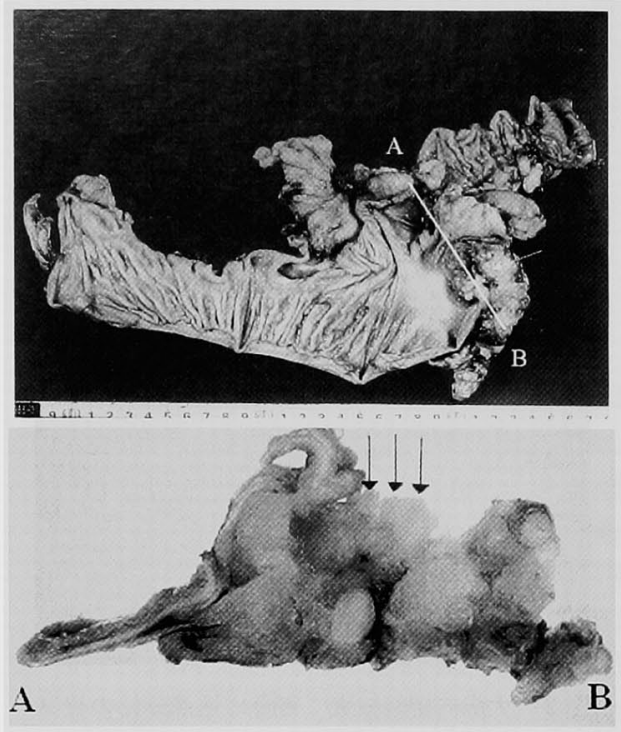

図 3 摘出標本所見：

a : 盲腸内腔虫垂開口部近くに 1 型腫湯を認めた (矢印).

b : ホルマリン固定後の切断面においてこの腫瘍 は上皮から由来していることを確認できた(矢印).

$\frac{\mathrm{a}}{\mathrm{b}}$

率はDPAM で75\%，68\% PMCA で14\%，3\% PMCA-I/D で50\%，21\%であることを示した。そして PMP という用語はDPAM として表現される虫垂粘 液腺腫に由来する病理学的にも, 予後的にも同一のグ ループのみに適応されるべきであると主張した. Ruth ら゙)は62例のレビューにおいて Ronnet らの分類を採 用し 3 年生存率が DPAM では $89 \%$, PMCA-I/D は37 $\%$ と両者に有意の相違を生じ, PMCA は従来の虫垂, 結腸癌による腹膜播種と予後に差がなかったことか ら, PMPはDPAM と PMCA-I/D のみに限定すべき であると主張している. Sugarbaker ら”も adenomucinosis, mucinous carcinomatosis, hybrid と表現は異なるものの悪性度に応じた同様の分類, 主 張を行っている.よって, PMP から PMCA を除外す る点では意見は一致しているものの, PMCA-I/Dの 取り扱いについては一致せず PMP から除外するのは 時期尚早と考える.

PMP はリンパ節転移や, 肝, 肺などの他㵴器転移が 極めて稀であり, 病変は腹腔内に留まる傾向にある。 そのため治療法としては第一に原発巣と腹腔内粘液物 質の可及的摘出（reduction surgery）を基本方針とす

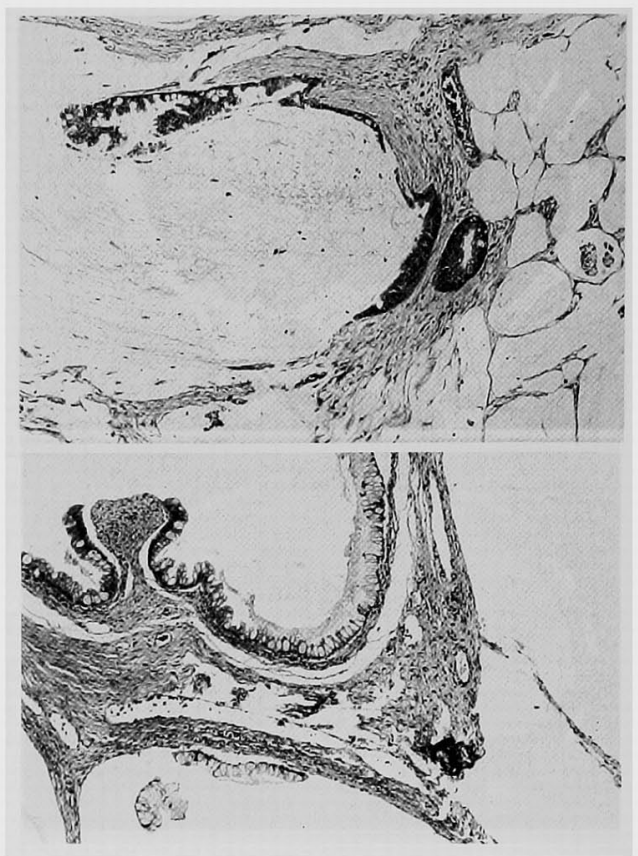

図4 組織所見 $(\mathrm{HE}$ 染色 $\times 100)$ :

a : 盲腸虫垂開口部の腫場は粘液産生の強い高分 化型腺癌の像を認め粘液湖を形成していた。 b：右卵巣は異型度の低い粘液産生細胞に裹打ち された纙胞性病変であった。

$$
\frac{a}{b}
$$

ることが一般的である ${ }^{8199}$.さらに補助療法として CDDP, 5-FU, MMC など抗癌剤の腹腔内投与や腹䐁 内温熱化学療法 ${ }^{5 / 61}$ ，ブドウ糖液やデキストラン製郕を 用いた粘液溶解療法が行われているが(0)11), まとまっ た症例を集めにくく治療効果に関しては明確なエピデ ンスがない(2). 腹腔内化学療法に関しては本邦でも 種々の投与法が試みられているが, CDDP50〜 100 m 術中腹腔内投与 ${ }^{13114}$ が汎用されて扔り, 術後も CDDP 投与を続けている例もある ${ }^{15)}$. なかでも佐々木らは 5

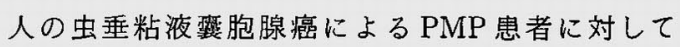
CDDP : $70 \mathrm{mg} / \mathrm{m}^{2} /$ day $1 \quad 5 \mathrm{FU}: 350 \mathrm{mg} / \mathrm{m}^{2} /$ day 1 $\mathrm{MMC}: 6 \mathrm{mg} / \mathrm{m}^{2} /$ day1 の腹腔内投与㧍よび $5 \mathrm{FU}$ : $350 \mathrm{mg} / \mathrm{m}^{2} /$ dayl-3 持続静注にて最長 6 年14カ月中央 値 2 年 8 力月の生存と良好な成績を報告している ${ }^{16)}$.

本症例は病理組織学的には原発巣に腺癌が存在する ものの粘液中には悪性度の高い上皮細胞がみられなか つたことから Ronnet らの言う PMCA-I/D に該当す ると思われるが術後 5 年間無再発生存中である. 前述 のごとく PMCA-I/D の 5 年生存率が $50 \%$ と良好であ 
るものの，本邦の過去 5 年間において検索しえた範囲 内では原発鉴が癌の症例（すなすち PMCA か PMCA -I/D)で術後 5 年以上無再発生存を確認している報告 はなかった。

Ruth $ら^{6)}$ が DPAM に対して reduction surgery みで対処した結果, その生存率は腹腔内, 全身化学療 法を加えた Ronnet ら5゙の結果とほぼ同じであったと 指摘しているように，今後はその悪性度に従って，治 療を選択する必要があると思われる。しかし開腹術に 先立って少量の生検材料からこれらのカテゴリーに分 類することは不可能なことが多い(2).また, PMCA-I/ DとPMCA それぞれに対する補助療法の有無に上る 治療成績の報告は無い。したがって, PMPに対してま す積極的に reduction surgeryを施行する.術中, 癌の 存在が否定できなければ腹腔リザーバーを留置する。 その後病理組織診断の結果により癌が証明された場 合, 腹腹もしくは全身化学療法を積極的に行うという 治療選択が考えられる。

\section{結語}

Reduction surgeryと術後 CDDP 腹腔内投与によ り 5 年間長期生存中の腹膜偽粘液腫の 1 例を経験した ので, 新しい分類とそれに基づく治療選択について若 干の文献的考察を加えて報告した。

\section{文献}

1) Sherer DM, Abulafia $O$, Eliakim $R$ : Pseudomyxoma peritonei. a review of current literature. Gynecol Obstet Invest $51: 73-80$, 2001

2) Uerrieri $C$, Franlund B, Fristedt $S$ : Mucinous tumor of the vermiform appendix and ovary, and pseudomyxoma peritonei : histogenetic implications of cytokeratin 7 expression. Hum Pathol 28: 1039-1045, 1997

3) Szych C, Staebler A, Connolly DC: Molecular genetic evidence supporting the clonality and appendiceal origin of pseudomyxoma peritonei in women. Am J Pathol 154 : 1849-1855, 1999

4) Jarome TO, James ST, Alice AR, et al: Pseudomyxoma Peritonei is a Disease of MUC2-Expressing Goblet Cells. Am J Pathol $161: 55 I-564,2002$

5) Ronnet BM, Yan H, Kurman RJ, et al : Patients with pseudomyxoma peritonei associated with disseminated peritoneal adenomucinosis have a significantly more favorable prognosis than patients with peritoneal mucinous carcinomatosis. Cancer 92:85-91, 2001

6) Ruth SV, Acherman YIZ, van de Vijver MJ, et al: Pseudomyxoma peritonei : a review of 62 cases. Eur J Surg Oncol 29:682-688, 2003

7) Sugarbaker $\mathrm{PH}$, Chang $\mathrm{D}$ : Results of treatment of 385 Patients With Peritoneal Surface Spread of Appendiceal Malignancy. Ann Surg Oncol $6: 727-731,1999$

8）金光幸秀，加藤知行，平井 孝：腹膜偽粘液腫の 診断と治療。癌と化療 $30: 614-618,2003$

9) Galani E, Marx GM, Steer $C B$, et al: Pseudomyxoma peritonei : the 'controversial' disease. Int J Gynecol Cancer 13:413-418, 2003

10) Beller FK, Zimmermann RE, Neinrich H : Biochemical identification of the mucus of pseudomyxoma peritonei as the basis for mucolytic treatment. Am J Obstet Gynecol 79 : 155-161, 1986

11) Roy WJ Jr, Thomas BL, Horowitz IR: Acute hyperglycemia following intraperitoneal irrigation with $10 \%$ dextrose in a patient with pseudomyxoma peritonei. Gynecol Oncol 65: 360-362, 1997

12) Moran BJ, Cecil TD: The etiology, clinical presentation, and management of pseudomyxoma peritonei. Surg Oncol Clin N Am 12:585 $-603,2003$

13）矢島文章, 小村伸朗, 柏木秀幸他：鼠径へルニア に対する手術を契機に発見された虫垂原発腹膜偽 粘液嗹の 1 例. 外科 $62: 831-833,2000$

14）田嶋勇介, 横山登, 田中孝幸他: 腹膜偽粘液腫 を伴った虫垂粘液整胞腺癌の 2 例. 手術 $55: 737$ $-741,2001$

15）鈴木恒夫，梅北镸孝，井上 䀘他：腹膜偽粘液腫 に対して CDDP 腹腔内投与を施行した 3 例. 癌と 化療 $25: 1449-1451,1998$

16) 佐々木章, 寺島雅典, 岡本和美他: 腹膜偽粘液腫 に対する CDDP, 5-FU, MMC 腹腔内投与療法。 癌と化療 26：1828-1831，1999 


\title{
PSEUDOMYXOMA PERITONEI ARISING FROM MUCINOUS CYSTADENOCARCINOMA OF THE APPENDIX WITH 5-YEAR SURVIVAL AFTER SURGERY -A CASE REPORT-
}

\author{
Yasuharu TOKUYAMA, Takashi HIRAI, Tomoyuki KATO, \\ Yukihide KANEMITSU and Hirotaka MIYAI \\ Department of Gastroenterological Surgery, Aichi Cancer Center
}

We report a case of pseudomyxoma peritonei arising from mucinous cystadenocarcinoma of the appendix with recurrence free survival 5 years after surgery. A 61-year-old woman who noticed lower abdominal distension was diagnosed with cecal cancer and bilateral ovarian metastases by colonoscopy's and CT. At laparotomy, jelly-like ascites and a child-head size tumor involving the right ovary, cecum and the appendix were found. Mucinous nodules scatterd throughout the abdominal cavity and mucinous mass scattered on the greater omentum, in the perisplenic region and in Douglas'pouch. We treated the patient by hysterectomy, bilateral oophorectomy, right hemicolectomy, and splenectomy, and removed as many mucinous nodules as possible. We also irrigated the abdominal cavity with $5 \%$ dextrose solution and repeated intraperitoneal chemotherapy with cisplatin and sodium thiosulfate after surgery. Histological examination revealed that the tumor was a pseudomyxoma peritonei derived from mucinous cystadenocarcinoma of the appendix, but no cancer cells were detected in the mucous ascitic fluid. 